IZA DP No. 708

Determinants of Trade Union Membership in Western Germany: Evidence from Micro Data, 1980-2000

Claus Schnabel J oachim Wagner

J anuary 2003 


\title{
Determinants of Trade Union Membership in Western Germany: Evidence from Micro Data, 1980-2000
}

\author{
Claus Schnabel \\ University of Erlangen-Nuremberg \\ Joachim Wagner \\ University of Lueneburg, HWWA Hamburg \\ and IZA Bonn
}

Discussion Paper No. 708

January 2003

IZA

P.O. Box 7240

D-53072 Bonn

Germany

Tel.: +49-228-3894-0

Fax: +49-228-3894-210

Email: iza@iza.org

This Discussion Paper is issued within the framework of IZA's research area Welfare State and Labor Market. Any opinions expressed here are those of the author(s) and not those of the institute. Research disseminated by IZA may include views on policy, but the institute itself takes no institutional policy positions.

The Institute for the Study of Labor (IZA) in Bonn is a local and virtual international research center and a place of communication between science, politics and business. IZA is an independent, nonprofit limited liability company (Gesellschaft mit beschränkter Haftung) supported by the Deutsche Post AG. The center is associated with the University of Bonn and offers a stimulating research environment through its research networks, research support, and visitors and doctoral programs. IZA engages in (i) original and internationally competitive research in all fields of labor economics, (ii) development of policy concepts, and (iii) dissemination of research results and concepts to the interested public. The current research program deals with (1) mobility and flexibility of labor, (2) internationalization of labor markets, (3) welfare state and labor market, (4) labor markets in transition countries, (5) the future of labor, (6) evaluation of labor market policies and projects and (7) general labor economics.

IZA Discussion Papers often represent preliminary work and are circulated to encourage discussion. Citation of such a paper should account for its provisional character. A revised version may be available on the IZA website (www.iza.org) or directly from the author. 
IZA Discussion Paper No. 708

January 2003

\begin{abstract}

\section{Determinants of Trade Union Membership in Western Germany: Evidence from Micro Data, 1980-2000*}

An empirical analysis of various waves of the ALLBUS social survey shows that union density fell substantially in West Germany from 1980 to 2000. Such a negative trend can be observed for men and women and for different groups of the workforce. Repeated crosssectional analyses suggest that a number of personal, occupational and attitudinal variables such as sex, occupational status, firm size and political orientation play a role in the unionization process, although the influence of many variables is not robust over time. While the results are consistent with cost-benefit considerations on the sides of employees and unions, individualization theory and social custom theory is not consistently supported by our estimations.
\end{abstract}

JEL Classification: J51

Keywords: $\quad$ trade union membership, Germany, micro data

Corresponding author:

Joachim Wagner

University of Lueneburg

Institute of Economics

21332 Lueneburg

Germany

Tel.: +494131782330

Fax: +494131782026

Email: wagner@uni-lueneburg.de

* This paper uses data from various ALLBUS surveys provided by the Zentralarchiv für Empirische Sozialforschung in Cologne. The authors alone are responsible for the use of the data in this study and for any conclusions drawn here. 


\section{Introduction}

The existence and the political and economic influence of trade unions depend on their ability to attract and nurture a loyal membership. Since in most industrialized countries unions are a crucial actor on the labour market and in the political arena, it is important to know which factors determine the extent and stability of union membership. Recent economic, sociological and political science literature contains an upsurge of theoretical and empirical work on unions and their membership. Interestingly, renewed interest in the area comes at a time when in many countries unions experience severe membership losses and reductions in union density (Ebbinghaus and Visser 2000, Visser 2003).

Germany is no exception to this trend. Union density, defined as the ratio of union members over employees, fell in the 1980s in West Germany, and has further fallen in the whole of Germany since unification in 1990 (see Müller-Jentsch and Ittermann 2000, Ebbinghaus and Visser 2000). Taking into account that official union member statistics are inflated by a large (but not precisely known) number of retired members gives a similar trend at a lower level and results in an estimate of net union density (i.e. active members over employees) for united Germany of about 22 per cent in 2000 (Ebbinghaus 2002).

Since this is a rough estimate due to limited information from unions on active and nonactive members, it may be interesting to see what survey data of employees can tell us about union density. More important, individual-level survey data enable us to analyse the determinants of union membership and to check whether these have changed over time. The few existing cross-sectional econometric analyses of union membership mainly use data from the 1970s and 1980s (Windolf and Haas 1989, Lorenz and Wagner 1991), while the most recent analysis by Fitzenberger et al. (1999) covers the year 1993. Therefore in this paper we make use of more recent data, drawing on the large ALLBUS surveys of employees for the period 1980 to 2000 , and we analyse the extent and the determinants of union membership in West Germany.

The structure of the paper is as follows: Section 2 provides an overview over traditional and more recent economic models of union membership while section 3 sketches explanations from other social sciences. Previous empirical approaches and evidence for Germany are described in section 4 . Section 5 presents the results of our own empirical investigation and 
identifies the main determinants of union membership in West Germany. Some conclusions and an outlook are provided in section 6.

\section{Economic modelling of union membership}

Traditionally, labour economists have analysed the forces that influence union membership within a conventional demand and supply framework. ${ }^{1}$ Beginning with Berkowitz (1954) and Pencavel (1971), union membership is considered as an asset in the portfolio of an utilitymaximizing worker that provides a flow of services, which are private and/or collective goods. The demand function expresses the demand of workers for union representation and services, while the supply function reflects the supply of union services.

Demand for union membership depends negatively on its costs (initiation fees and dues) relative to the price of other goods and assets, whereas wealth or permanent income should influence union membership positively if union services are a normal good. The larger the (expected) union-nonunion wage differential, the more likely are employees to join a union. However, since the relative wage differential cannot in general be measured directly, studies often examine the relationship of unionism with personal and industry characteristics (such as age, skills and industry concentration), which serve as proxies for the expected benefits of union representation. In addition to wage gains, net non-pecuniary benefits from a unionised work environment such as better working conditions and grievance procedures (proxied by firm size, accident risk etc.) can also be expected to stimulate demand for union representation. In contrast, the lower the cost of substitute services (such as social welfare benefits), the lower demand for union services should be. Finally, individual's taste for unionism can affect the demand for union membership. This variable is meant to reflect workers' attitudes and preferences, ideological motives, social pressure and custom, and related non-economic variables stressed by other disciplines of social science.

Although unions may not be typical profit maximizers, they face a binding budget constraint in that they must fund union organizing, services and the like, which means that they must pay attention to revenues and (opportunity) costs. Therefore the supply of union services depends positively on revenues whereas the costs of union organizing and the costs of servicing existing members both affect supply negatively. Organizing and servicing costs are

\footnotetext{
${ }^{1}$ This sort of analysis is described in more detail by Hirsch and Addison (1986, ch. 2.5) and Schnabel (2003).
} 
likely to have a fixed-cost component so that collective bargaining exhibits decreasing unit costs with respect to membership, and unionism is therefore less likely in small firms. Both the costs of organizing and of servicing will be affected by employers' attitudes toward unions and collective bargaining, and they can be influenced substantially by the legal structure within which unions may operate. Furthermore union goals (such as maximizing membership or a certain utility function) may affect the supply of union services in various ways.

Empirical studies generally estimate some variant of a reduced-form equation combining the supply and demand functions. Since most of the variables sketched above cannot be measured directly, they are often substituted for by proxy variables (such as firm size and personal characteristics). However, these variables are likely to affect unionism through more than one channel, so that interpretation is difficult. In addition to measurement problems in the explanatory variables of the reduced-form equation, the amount of union services is also not directly observed. Assuming that the level of services is proportional to the level of unionization, direct measures of union membership, union density or bargaining coverage can be used to proxy union services. The appropriateness of each union measure depends on the econometric design of the study, the data available and the legal framework.

However, this sort of cost-benefit analysis of union membership determination does not pay enough attention to an important problem unions face in most countries, namely the freerider problem. Many of the services unions provide - such as higher wages and better working conditions - accrue both to union members and non-members in the workplace. These services can be seen as public or collective goods since they are nonrival in consumption and low-cost exclusion of non-members is not possible. Hence an individual has a free-rider incentive not to join the union. The key problem for the economist is to explain why any individual would join a union when dues are costly and when the benefits apply to all workers regardless of their union status. ${ }^{2}$

\footnotetext{
${ }^{2}$ In a median voter model in which workers have different reservation wages and hence different optimal points in the trade-off between an increased wage and a decreased probability of employment, Bulkley and Myles (2001) argue that joining a union instead of free-riding may be rational if it enables individuals to influence union bargaining goals and thus their own employment probability.
} 
While in small groups the free-rider problem may not be insurmountable, the difficulty is to explain why large groups providing collective goods such as trade unions manage to exist despite the free-rider problem. In his path-breaking analysis of collective action, Olson (1965) argued that a large group can only have formed for two reasons: Either because membership is compulsory (this would be the case of the "closed shop" in which union membership is a condition of employment) or because the group offers selective incentives in the form of private goods and services available only to its members (with ancillary provision of the collective good as a "byproduct"). ${ }^{3}$ In many countries, however, closed shops are either illegal or are rarely found anymore, and the widespread presence of "open shop" unions (where membership is voluntary) suggests that selective incentives such as strike pay and legal support available to members may seem to be more important for joining a union.

In addition to such material selective incentives, Booth (1985) has suggested to interpret the incentive private good as being the „reputation“ utility that derives from complying with a social custom of union membership. This idea stems from Akerlof (1980) and takes up an argument commonly put forward by sociologists and psychologist, namely that within a community there is a set of rules and customs that are obeyed by individuals because of the sanction of a loss of reputation if the custom should be disobeyed. In the context of union membership, the social custom can be thought of as urging workers not to free-ride. Following social custom theory, Booth (1985) and Naylor (1990) have proposed models in which it is assumed that workers directly derive utility from the reputation effect of belonging to a union, and which show that a union can exist despite the free-rider problem if it achieves a minimum critical density. In the social custom approach, the decision to join is interdependent and - contrary to the Olson (1965) free-rider paradox - workers may be more prepared to join a union if others are joining. ${ }^{4}$

Within this framework, Naylor and Cripps (1993) have shown that when workers' tastes are heterogeneous with respect to their sensitivity to reputation, stable intermediate union density is a possible equilibrium outcome. They provide an explanation of voluntary

\footnotetext{
${ }^{3}$ As regards unions, Olson $(1965,75)$ thought that "[i]n most cases it is compulsory membership and coercive picket lines that are the source of the union's membership“.

${ }^{4}$ Naylor (1990) demonstrates the formal equivalence of the Booth (1985) model and the "critical mass" or "tipping" models developed by Schelling (1978) and discussed by Marwell and Oliver (1993); see also the "resource mobilization" approach by Klandermans (1984).
} 
membership of the open shop trade union in which the union density level is likely to increase as a result of a reduction in union membership costs, an increase in strike pay or an increase in individuals' sensitivity to the social custom of union membership and the associated solidarity effects. Extensions of the social custom model taking into account employer behaviour in form of management opposition to union membership have been proposed by Naylor and Raaum (1993) and by Corneo (1995). They show that a stable long-run equilibrium may exist, in which strong unions persist in spite of management opposition. Furthermore, Booth and Chatterji (1993) provide a model of union membership and wage determination which predicts that the open shop union is viable only after membership has achieved a minimum critical density, and wages are at a sufficient level to support this.

One problem of social custom models is that they leave unexplained the formation of the social custom. ${ }^{5}$ This is circumvented by another strand of literature that combines a similar formal approach with the hypothesis that unions provide pure private goods to their members instead of reputation. Booth and Chatterji (1995) develop a theoretical model of the simultaneous determination of union wages and membership which points to the existence of excludable private goods as an important factor motivating workers to join unions in the absence of coercive closed shop rules. ${ }^{6}$ Their results suggest that unions concerned with density will have to rely on devising excludable private goods such as grievance procedures or influence over manning arrangements to attract members since increasing wages alone will not increase density. In contrast, Moreton $(1998,1999)$ makes use of the (empirically supported) assumption that union members enjoy greater job security than do non-members in the form of a reduced probability of dismissal for reasons other than redundancy. Thus the private good of increased job security acts as a selective

\footnotetext{
${ }^{5}$ Corneo (1997) tries to provide a microfoundation of the social custom approach by endogenizing the reputation effect of belonging to the union as the outcome of a signalling game among the workers. Depending on societal values, various shapes of the reputation effect may arise. If conformism prevails in the workers ' community, the reputation effect increases with union density; if elitism prevails, the opposite applies.

${ }^{6} \mathrm{~A}$ prominent example of a such an excludable private good is a union-run unemployment insurance known as the Ghent system. A formal theoretical analysis by Holmlund and Lundborg (1999) shows that the Ghent system is more conducive to unionization than a compulsory unemployment system if it is heavily subsidized by the government or if workers are strongly risk averse.
} 
incentive to join the union. Less effective job protection by unions and lower union bargaining power are predicted to reduce union density. ${ }^{7}$

One corollary of most of the models discussed above is that a reduction in union membership caused by temporary shocks is likely to be persistent (Calmfors et al. 2001, 18). If membership is reduced, the process of rebuilding can be lengthy and even unsustainable since there exists a minimum critical mass of membership or density below which union existence is not viable. In the absence of coercion the open shop union's provision of services may be crucial in obtaining its critical level of density. Union density is likely to increase with the quality of the services provided, while at the same time the size and density of the union may positively affect the provision of services due to economies of scale. If, however, union-like services are available elsewhere at lower cost or if the provision of certain welfare benefits by government substitutes for the private provision by unions (as stressed by Streeck 1981 and Neumann and Rissman 1984), the attractiveness of union membership will be reduced and unions may face serious problems of survival.

\section{Explanations from other social sciences}

In addition to pure economic reasoning, social, psychological and political factors may also contribute to explaining the level and development of union membership. Sociologists and political scientists have long stressed the importance for union density of factors such as class consciousness, values, modes of production, the composition of the workforce, the political climate, the role of government incomes policies, and the centralisation and cohesiveness of the labour movement (see, for instance, Beyme 1981 and Streeck 1981). Some of these potential determinants have been incorporated in the economic models of unionization described above. Other influential theories explaining individual behaviour will be briefly sketched now without the pretention of exhaustiveness. ${ }^{8}$

\footnotetext{
${ }^{7}$ In a different setting, Jones and McKenna (1994) show that in case a union is able to offer greater employment protection for its members, employed workers join the union if the marginal benefit of protection is at least as great as union dues, and their dynamic model permits a variety of relationships between employment and membership in the adjustment to steady state.

${ }^{8}$ Examples of psychological and socio-political approaches to unionization can be found, inter alia, in Crouch (1982), Klandermans (1984, 1986), Guest and Dewe (1988), Wallerstein (1989), Windolf and Haas (1989), Western (1997), Rij and Daalder (1997) and Visser (2002).
} 
Following Klandermans (1986), three theoretical and partly overlapping approaches to trade union participation can be distinguished within the social psychology, namely the frustrationaggression approach, the rational-choice approach and the interactionist approach. The frustration-aggression approach explains union membership as a result of individuals frustration, dissatisfaction or alienation in their work situation (and membership resignation in terms of frustration with union policies). However, dissatisfaction "is neither a necessary nor a sufficient condition for participation" (Klandermans 1986, 199). Furthermore, from an economic point of view, this sort of joining and quitting behaviour could be interpreted as reflecting cost-benefit considerations and may be incorporated in standard explanations of the demand for unions.

The rational-choice approach interprets unionization as the outcome of a process of weighing the costs and benefits of participation (a prominent example is Crouch 1982). Of course, such an approach also underlies economic theories of unionization, but economists often pay attention only to individual, selective costs and benefits. In contrast, social scientists try to take a broader view and point out that the decision to join a union can also be influenced by collective, social and ideological motives, which may be difficult to measure. The balance of costs and benefits, combined with expectations about the degree to which the union will be able to realize these motives, determine the actual membership decision.

In the interactionist approach union participation is inextricably bound up with group culture, and an individual's decision to join a union is strongly influenced by his social context, i.e. his living and working environment (see also social identity theory, e.g. Tajfel 1982). Concerning the living environment, tradition and prevailing opinions within someone's group are important because here general beliefs are formed about unions even before the employment relationship is entered into. Starting with Booth (1985) this line of reasoning has been incorporated into the social custom models of union membership discussed in the previous chapter which in some sense blend interactionist and rational-choice explanations. Concerning the working environment, the prevailing union density in an individual's establishment or industry and the contact with the union at the workplace may play a role. While this is also recognized in some economic explanations of union membership and growth, economists have tended to concentrate on the demand side of unionism and have paid less attention to the supply side, for example the union's decision to allocate resources to the recruitment of new members. 
It is obvious that social scientists provide other explanations or emphasize different determinants of unionization than economists. Some of these factors can be incorporated in the economist's supply-demand and cost-benefit framework discussed above whereas others are more difficult to operationalize. Empirical studies of the determinants of union membership usually take an eclectic approach and combine economic as well as sociopolitical hypotheses and explanations.

\section{Empirical approaches and evidence}

The preceding sections have identified a large number of economic, social and political variables that according to theoretical considerations can be expected to influence individuals' decision to unionise and affect union membership. Empirical analyses, however, in many cases have not directly followed the lines of theoretical research. This divergence is partly due to the fact that the progress of the theoretical literature as to why employees belong to a union has been slow, and often empirical findings preceded or prompted theoretical research. In addition it reflects an eclectic approach of many empirical studies that mix economic, social and political variables.

By and large, empirical analyses of union membership fall within one of three approaches: ${ }^{9}$ The first (and oldest) strand of literature stresses cyclical explanations and attempts to identify the macro-determinants of union growth and decline by means of time-series studies in the spirit of Ashenfelter and Pencavel (1969) and Bain and Elsheikh (1976). From these sort of studies there is some evidence across countries that business cycle factors as well as structural developments play a significant role in explaining short-run changes and longrun trends in union membership (see the surveys by Chaison and Rose 1991 and by Schnabel 2003). The second strand of literature provides structural explanations of union membership and concentrates on individual characteristics of union (and non-union) members as well as on sectoral and occupational factors. These individual-level (or firmlevel) cross-sectional studies have identified a number of micro-determinants such as personal, occupational and firm characteristics, attitudes and social variables that are associated with the unionisation decision (see the surveys by Wheeler and McClendon

\footnotetext{
${ }^{9}$ For a similar classification see Ebbinghaus and Visser (1999), who distinguish cyclical, structural and configurational (or institutional) explanations of union growth and decline, and Calmfors et al. (2001).
} 
1991, Riley 1997 and Schnabel 2003). ${ }^{10}$ Finally, a third strand favours institutional explanations and analyses cross-national variations in institutional settings assumed to influence unionization such as a closed shop or a union-affiliated unemployment insurance (see, e.g., Western 1997, Ebbinghaus and Visser 1999, Blaschke 2000).

While the third approach relies on cross-national data and cannot be pursued for one country only, the other two approaches may also be found in Germany. Aggregate timeseries analyses in the business cycle tradition have shown that economic variables such as wage and price inflation, employment growth and unemployment influence union membership growth (see Brauckmann 1972, Armingeon 1989 and Schnabel 1989). In addition, the composition of the labour force plays a significant role, in particular in explaining long-run trends in unionisation (Carruth and Schnabel 1990). The potential influence of political variables such as indicators of parliamentary representation is opaque (see Armingeon 1989 and Schnabel 1989 for conflicting empirical evidence). While these aggregate studies provide some insights into the macro-determinants of union growth, it is difficult to interpret their results in terms of individuals' decisions and cost-benefit considerations which underly theoretical models of unionization.

Therefore empirical research as to why individuals belong to a union has made use of crosssectional studies that seek to identify the micro-determinants of unionization by analysing differences in unionization across units at a point in time rather than variations over time. ${ }^{11}$ While there exist some studies investigating unionization at the establishment level (see, e.g., Klodt and Meyer 1998 for Germany), the majority of cross-sectional analyses focus on individual-level data of union and non-union employees. Among (western) German studies, Windolf and Haas (1989) use data from eight representative surveys between 1976 and 1984, whereas all other analyses rely on data from the German Socio-Economic Panel, covering either the year 1985 (Lorenz and Wagner 1991, Wagner 1991) or the years 1985, 1989 and 1993 (Goerke and Pannenberg 1998, Fitzenberger et al. 1999). While all five

\footnotetext{
${ }^{10}$ Determinants of unionization are thus analysed by comparing the characteristics of union and non-union employees or firms, but with few exceptions (see Waddington and Whitston 1997; Rij and Daalder 1997; Visser 2002), the process of joining a union itself is not the object of these studies.

${ }^{11}$ Obviously it is difficult to clearly distinguish between macro- and micro-determinants of unionism, and the distinction above mainly relates to the different empirical approaches applied. Time-series and cross-sectional studies and their empirical results should be seen as complements whose relationship is interpreted by Riley
} 
studies find establishment size to be a significant determinant of unionization, other significant covariates differ widely between (and even within) studies depending on the data set and the year analysed and on the econometric specification used.

This suggests that it may be worthwhile to take up an econometric investigation that covers a longer observation period and that estimates the same equation at several points in time in order to see which variables actually explain an individual's probability of being a union member and whether the influence of these variables has changed over time. Such a change has been predicted by Beck $(1983,1994)$ who argues on the basis of individualization theory that collective and group-specific orientation schemes have lost their importance over time. In an attempt to test this hypothesis empirically, Schnell and Kohler (1995) analyse a large number of different German surveys since 1953 and find that the explanatory power of socio-demographic characteristics for voting behaviour and for union membership decreases over time, but they do not specify a full model of union membership and they do not report details of their estimates.

\section{Empirical analysis}

The data used in this study are taken from various waves of the ALLBUS, the German general social survey. This survey has been conducted every second year since 1980, and for a nominal fee the data are available for scientific research. Note that the ALLBUS data sets are not part of a panel study; for each wave an independent random sample is drawn covering people aged 18 years or more. An additional baseline survey was conducted in 1991 shortly after German unification, and since then the samples include residents in the new federal states in eastern Germany and (German-speaking) foreigners. ${ }^{12}$

Since we are interested in the long-run development of unionization and in order to be consistent and able to analyse possible changes in the determinants of membership without potential biases from German unification ${ }^{13}$, we restrict our sample to employees in the

(1997, p. 270) as follows: "Whilst both approaches are valuable, individual-level studies may enjoy a higher ability to detect the morphology of the causal links whose effects have been identified on a macro-level."

${ }^{12}$ For additional information on the ALLBUS, see Terwey (2000). In order to facilitate replications and extensions, the STATA do-files used in this study are available from the second author on request.

${ }^{13}$ Differences in (and the convergence of) union membership between eastern and western Germany are investigated in a companion paper; see Schnabel and Wagner (2003). 
former West Germany throughout the observation period 1980 to 2000 . Foreigners are excluded because they were not covered in the years before 1991 and because they form a small and rather heterogeneous proportion of the samples. We look at individuals who were 18 to 64 years old and who were working full time or part time, either as blue collar workers, white collar workers (except top managers) or civil servants (Beamte).

Table 1 presents (in intervals of four years) information on union density available from our sample. In contrast to usual calculations of density rates that rely on union figures and therefore include active and retired members in the numerator (see e.g. Müller-Jentsch and Ittermann 2000), our ALLBUS data refer to employees only and enable us to calculate a more realistic net density rate defined as the percentage of union members among West German employees. Although the 95 per cent confidence intervals are quite large, it is obvious from Table 1 that union density fell substantially in the observation period. While in 1980 one in three employees was a union member, in 2000 this was only the case for a quarter of employees. Such a negative trend can be observed for men and women and for different groups of employees. In 2000, density was particularly low for women (17.7 percent) and for white collar workers (18.5 percent), whereas blue collar workers and civil servants were still union strongholds.

(Table 1 about here)

The ALLBUS data allow us to investigate the determinants of union membership because they include information on a number of potential covariates such as personal and occupational characteristics, attitudes and family background. Since the dependent variable in our investigation is a 1/0-dummy indicating whether an employee is a union member or not, a probit analysis (estimating the probability of union membership) is appropriate.

In many countries union membership has been found to be systematically related in crosssectional studies to a number of personal characteristics such as sex, age and education (see the surveys by Riley 1997 and Schnabel 2003). Table 1 shows that in Germany (as in most other countries) men exhibit a higher union density than women. This stylised fact has traditionally been interpreted as a reflection of mens' greater degree of attachment to the labour force which would increase the benefits of unionization both from the point of view of workers and of unions. A similar reasoning applies to full time workers, and dummy variables for sex and full time working are therefore included in the analysis. The few 
disaggregated union statistics available also indicate that density among young workers is below average which is said to reflect a different socialisation of young workers resulting in lower identification with unions, a related change of values, and difficulties of recruiting young workers which in Germany are often trained in small and medium-sized firms where union density is lower (see, e.g. Schnabel and Pege 1992). Therefore an age variable is included in the analysis, and it will be interesting to see whether the bivariate relationships suggested by union statistics also hold in multivariate settings.

In contrast to published union statistics the ALLBUS survey also contains information on the educational and qualificational background of union members. We are able to include dummy variables in our analysis that take on the value of 1 if employees have finished an apprenticeship or are master craftsmen and if they have a polytech or university degree. For the former variable we would expect a positive influence on unionisation since unions have developed and have traditionally served as representatives of skilled craftsmen and since recruitment costs should be relatively low for this rather homogeneous group (with high employment security) that forms the backbone of the German industrial workforce. In contrast, a polytech or university degree is assumed to be negatively associated with unionism because more educated employees have greater individual bargaining power (and thus a lesser need for collective voice) and because sometimes they identify more with management than with the labour movement.

The occupational status of employees is included in the analysis by dummy variables for blue collar workers and civil servants which again enable us to test whether the relationships showing up in Table 1 also hold in a multivariate analysis. Since blue collar workers and civil servants have rather homogeneous preferences and working conditions which make them easier to organize they are expected to have a higher probability of being union members.

Workplace and firm characteristics are reflected in a dummy variable for employees working in the public sector and by a firm size variable consisting of the number of employees and its square (which, however, is only available for the year 1980). Since union recruitment tends to be easier and less costly in large, homogeneous organizations with a bureaucratic nature and a low turnover rate, unionization is expected to be higher in the public sector than in the market sector. Similarly, we expect a positive but decreasing impact of firm size reflecting lower organizing costs for unions in larger units. In addition, union services may be valued most highly in large, bureaucratic organizations where workers are likely to be treated 
impersonally and feel a greater need for representation and protection. In such organizations there may also exist higher peer pressure to conform to a social custom of union membership (as suggested by Riley 1997). Finally, in the public sector and in larger firms there exist substantially more works councils than elsewhere (cf. Addison et al., 2002), and since works councils usually are prime actors of union recruitment (Streeck, 1981, 209ff.), the propensity to join a union should be higher there.

In addition to establishment size, some studies have also paid attention to the location of a company and have found significant effects of urbanization (see, e.g., the studies by Antos et al. 1980 for the U.S. and Berg and Groot 1992 for the Netherlands). This has never been tested for Germany although an older survey published by Deppe $(1979,57)$ points to a positive bivariate relationship between the size of a community and union density. Since our data set contains information on the size of the village or city where the individuals live (but not where they work), we are able to include in our estimations an index of the size of the agglomeration (with values increasing from 1 for less than 2,000 inhabitants to 7 for 500,000 and more), and we expect a positive relationship with union membership. There are two main reasons for this hypothesis: The first relates to union recruitment costs that should be lower in large agglomerations (which also have an above-average share of large companies). Secondly, large agglomerations usually have a longer tradition of unionisation, and the employees often have experienced a longer and intensive "industrial socialization" which makes them more likely to join a union (cf. Müller-Jentsch 1987).

Political attitudes of individual employees have been found to be significant determinants of union membership in many studies (see the surveys by Riley 1997 and Schnabel 2003). For Germany, Windolf and Haas (1989), Lorenz and Wagner (1991) and Fitzenberger et al. (1999) all found that Social-Democrat (SPD) voters have a higher probability of being union members which is not surprising given the historically close relationship between the SPD and the labour movement. In the ALLBUS data set there is information on the political orientation of respondents measured on a ten-point scale ranging from 1 for extreme left to 10 for extreme right. Since left-wing views should be associated with a higher probability of union membership we expect a negative coefficient of this variable in our estimations.

Several theories of social psychology as well as social custom models suggest to include social variables into individual-level cross-sectional studies of unionization. In Germany, the influence of reference groups and key individuals such as parents and spouses on the 
decision maker has been investigated with mixed success by Windolf and Haas (1989) and Goerke and Pannenberg (1998). Our data set contains information on whether an employee's father was a blue collar worker, and we expect this dummy variable to have a positive influence on the probability of union membership due to a union-friendly socialization process in the family.

(Table 2 about here)

Table 2 presents the results of our estimations separately for the years 1980, 1984, 1988, 1992, 1996 and 2000 as well as for all data pooled. It should be noted that the question on the political orientation of employees was not asked in 1984 (which means that the pooled estimations do not include the year 1984) and that information on firm size was only available in 1980 and 1984 . Starting with the latter variable, the results in the first two columns show that the probability of union membership significantly increases with the size of the firm (although the negative squared term indicates that this happens at a decreasing rate). Because of this important result, which is consistent with previous empirical evidence for Germany and with recruitment considerations and social customs, we decided to include the firm size variable in the estimations for 1980 and 1984, whereas the estimations for the other years and the pooled estimations do not contain a firm size variable.

Looking first at the pooled estimations in the last column, it can be seen that men, blue collar workers and civil servants are significantly more likely to be union members, which reinforces the descriptive evidence from Table 1 and from union statistics. The same can be said for full time workers, for employees in the public sector and for those whose father was a blue collar worker. In contrast, employees with a polytech or university degree are less likely to join a union. The probability of union membership significantly increases with the age of an employee and with the size of the agglomeration he or she lives in. Individuals' political orientation also plays a significant role in that moving to the right of the political spectrum is associated with a falling probability of being a union member.

A closer look reveals, however, that only one of these variables, namely political orientation, exerts a significant influence on union membership in all years investigated. Three other variables, namely full time worker, blue collar worker and civil servant, are significant in five 
of the six cross-sections studied, and sex and public sector prove significant four times. ${ }^{14}$ The influence of the other variables suggested by the results of the pooled estimations is far from robust and has to be interpreted with (more than) a pinch of salt.

Concentrating on the more robust explanatory variables, personal and occupational characteristics as well as political attitudes seem to be the most important determinants of union membership in (West) Germany. The persistent influence of political orientation, full time worker and blue collar worker status stands in contrast to the individualization hypothesis by Beck $(1983,1994)$ that collective and group-specific orientation schemes have lost their importance over time, but the fading importance of the variable indicating a blue collar status of the father may be consistent with this view.

\section{Conclusions}

The empirical evidence from repeated cross-sectional analyses for the period 1980 to 2000 suggests that a number of personal, occupational and attitudinal variables such as sex, occupational status, firm size and political orientation play a role in the unionization process in Germany, although the influence of many variables is not robust over time. There is, however, the problem that cross-sectional analyses can only detect correlations between variables and are not able to answer questions of causality. This problem should be borne in mind in particular when interpreting the significant relationship found between an individual's union membership on the one hand and his left-wing views on the other. Furthermore, the process of joining or leaving a union and the role played by union recruitment strategies and works councils could not be investigated due to lack of data, but it would be a promising area of further research.

Our empirical findings do not enable us to clearly discriminate between alternative (but often related) theories from economics, social psychology and industrial relations. This reinforces the impression from the wider literature that it has proved difficult to build a bridge between the variety of theoretical approaches and the empirical literature on the determinants of unionization (see Schnabel 2003). While the statistical significance of personal, occupational and firm characteristics is consistent with cost-benefit considerations on the sides of employees and unions and with rational choice theory, individualization theory and social

\footnotetext{
${ }^{14}$ We thus cannot confirm and extrapolate the result by Windolf and Haas $(1989,161)$ who found that in the
} 
custom theory is not consistently supported by our estimations (which however could only make use of one social custom variable). Future empirical analyses should try to include more social custom variables and compare their impact with that of pure private good incentives. Not only here, the lack of adequate data is a major problem. The new representative large-scale panel data of individuals and firms built up recently in some countries in the form of employer-employee data sets are no panacea unless they also identify union members (what they usually fail to do).

Despite these qualifications, the descriptive evidence in Table 1 and our estimations in Table 2 paint a bleak picture for the future of the union movement in Germany. Besides political attitudes (which might be difficult to influence by union actions) the most robust determinants of union membership are found to be sex and occupational characteristics. As the employment share of men, blue collar workers, civil servants and full time workers has been falling constantly, union membership and density can be expected to decline further unless the unions manage to be more successful in recruiting growing groups of the labour force such as women, white collar workers and employees the private service sector. Nobody knows whether there exists a minimum critical mass of membership or density below which union existence is not viable (as predicted in recent economic models) and where this threshold lies, but it is clearly high time for the unions to reverse the negative trend if they further want to play the important political and economic role which they still occupy in the German system of corporatism.

\section{References}

Addison, John T. / Bellmann, Lutz / Schnabel, Claus / Wagner, Joachim (2002), German Works Councils Old and New: Incidence, Coverage and Determinants, IZA Discussion Paper No. 495, Institute for the Study of Labor (IZA), Bonn.

Akerlof, George A. (1980), A Theory of Social Custom, of Which Unemployment May Be One Consequence, Quarterly Journal of Economics, 95, 749-775.

Antos, Joseph R. / Chandler, Mark / Mellow, Wesley (1980): Sex Differences in Union Membership, Industrial and Labor Relations Review, 33, 162-169.

Armingeon, Klaus (1989): Trade unions under changing conditions: the West German experience, 1950-1985, European Sociological Review, 5, 1-23. 
Ashenfelter, Orley / Pencavel, John H. (1969): American Trade Union Growth: 1900-1960, Quarterly Journal of Economics, 83, 434-448.

Bain, George S. / Elsheikh, Farouk (1976), Union Growth and the Business Cycle: An Econometric Analysis, Oxford.

Beck, Ulrich (1983): Jenseits von Stand und Klasse?, in: Kreckel, Reinhard (ed.), Soziale Ungleichheiten, Göttingen, 35-74.

Beck, Ulrich (1994): The Debate on the Individualization Theory in Today's Sociology in Germany, Soziologie - Journal of the Deutsche Gesellschaft für Soziologie, Special Edition 3, 191-200.

Berg, Annette van den / Groot, Wim (1992): Union Membership in the Netherlands: A CrossSectional Analysis, Empirical Economics, 17, 537-564.

Berkowitz, Monroe (1954): The Economics of Trade Union Organization and Administration, Industrial and Labor Relations Review, 7, 537-549.

Beyme, Klaus von (1981): Challenge to Power: Trade Unions and Industrial Relations in Capitalist Countries, London.

Blaschke, Sabine (2000): Union Density and European Integration, European Journal of Industrial Relations, 6, 217-236.

Booth, Alison L. (1985): The Free Rider Problem and a Social Custom Model of Trade Union Membership, Quarterly Journal of Economics, 100, 253-261.

Booth, Alison L. / Chatterji, Monojit (1993): Reputation, Membership and Wages in an Open Shop Trade Union, Oxford Economic Papers, 45, 23-41.

Booth, Alison L. / Chatterji, Monojit (1995): Union Membership and Wage Bargaining when Membership is not compulsory, Economic Journal, 105, 345-360.

Brauckmann, Gerhard (1972): Der Einfluß des Konjunkturverlaufs auf die gewerkschaftlichen Mitgliederbewegungen, PhD Dissertation, Ruhr University Bochum.

Bulkley, George / Myles, Gareth D. (2001): Individually rational union membership, European Journal of Political Economy, 17, 117-137.

Calmfors, Lars / Booth, Alison / Burda, Michael / Checci, Daniele / Naylor, Robin / Visser, Jelle (2001): The Future of Collective Bargaining in Europe, in Boeri, Tito / Brugiavini, Agar / Calmfors, Lars (eds), The Role of Unions in the Twenty-First Century, Oxford, 1-155.

Carruth, Alan / Schnabel, Claus (1990): Empirical Modelling of Trade Union Growth in Germany, 1956-1986: Traditional versus Cointegration and Error Correction Methods, Weltwirtschaftliches Archiv, 126, 326-346.

Chaison, Gary N. / Rose, Joseph B. (1991): The Macrodeterminants of Union Growth and Decline, in: Strauss, George / Gallagher, Daniel G. / Fiorito, Jack (eds.), The State of the Unions, Madison, WI, 3-45. 
Corneo, Giacomo (1995): Social custom, management opposition, and trade union membership, European Economic Review, 39, 275-292.

Corneo, Giacomo G. (1997): The theory of the open shop trade union reconsidered, Labour Economics, 4, 71-84.

Crouch, Colin (1982): Trade Unions: the Logic of Collective Action, Glasgow.

Deppe, Frank (1979): Autonomie und Integration: Materialien zur Gewerkschaftsanalyse, Marburg.

Ebbinghaus, Bernhard (2002): Dinosaurier der Dienstleistungsgesellschaft? Der Mitgliederschwund deutscher Gewerkschaften im historischen und internationalen Vergleich, MPIfG Working Paper 02/3, Max Planck Institute for the Study of Societies, Cologne, March 2002.

Ebbinghaus, Bernhard / Visser, Jelle (1999): When Institutions Matter - Union Growth and Decline in Western Europe, 1950-1995, European Sociological Review, 15, 135-158.

Ebbinghaus, Bernhard / Visser, Jelle (2000): Trade Unions in Western Europe since 1945, Basingstoke.

Fitzenberger, Bernd / Haggeney, Isabelle / Ernst, Michaela (1999): Wer ist noch Mitglied in Gewerkschaften? Eine Panelanalyse für Westdeutschland, Zeitschrift für Wirtschafts- und Sozialwissenschaften, 119, 223-263.

Goerke, Laszlo / Pannenberg, Markus (1998): Social Custom, Free-Riders, and Trade Union Membership in Germany and Great Britain, DIW Discussion Paper No. 177, Berlin, December 1998.

Guest, David E. / Dewe, Philip (1988): Why Do Workers Belong to a Trade Union? A Social Psychological Study in the UK Electronics Industry, British Journal of Industrial Relations, 26, 178-194.

Hirsch, Barry T. / Addison, John T. (1986): The Economic Analysis of Unions, London.

Holmlund, Bertil / Lundborg, Per (1999): Wage bargaining, union membership, and the organization of unemployment insurance, Labour Economics, 6, 397-415.

Jones, Stephen R. G. / McKenna, C. J. (1994): A Dynamic Model of Union Membership and Employment, Economica, 61, 179-189.

Klandermans, Bert (1984): Mobilization and Participation: Social-Psychological Expansions of Resource Mobilization Theory, American Sociological Review, 49, 583-600.

Klandermans, Bert (1986): Psychology and trade union participation: Joining, acting, quitting, Journal of Occupational Psychology, 59, 189-204.

Klodt, Thomas / Meyer, Wolfgang (1998): Empirical Analysis of Inter-firm Differences in Trade Union Density, Discussion Paper No. 13, Universität Hannover, Forschungsstelle Firmenpanel, July 1998. 
Lorenz, Wilhelm / Wagner, Joachim (1991): Bestimmungsgründe von

Gewerkschaftsmitgliedschaft und Organisationsgrad, Zeitschrift für Wirtschafts- und Sozialwissenschaften, 111, 65-82.

Marwell, G. / Oliver, P. (1993): The Critical Mass in Collective Action: A Micro-Social Theory, Cambridge.

Moreton, David (1998): An open shop trade union model of wages, effort and membership, European Journal of Political Economy, 14, 511-527.

Moreton, David (1999): A model of labour productivity and union density in British private sector unionised establishments, Oxford Economic Papers, 51, 322-344.

Müller-Jentsch, Walther (1987): Eine neue Topographie der Arbeit - Organisationspolitische Herausforderungen für die Gewerkschaften, in: Abromeit, Heidrun / Blanke, B. (eds.), Arbeitsmarkt, Arbeitsbeziehungen und Politik in den 80er Jahren, Opladen, 159-178.

Müller-Jentsch, Walther / Ittermann, Peter (2000): Industrielle Beziehungen: Daten, Zeitreihen, Trends 1950-1999, Frankfurt am Main.

Naylor, Robin A. (1990): A Social Custom Model of Collective Action, European Journal of Political Economy, 6, 201-216.

Naylor, Robin / Cripps, Martin (1993): An economic theory of the open shop trade union, European Economic Review, 37, 1599-1620.

Naylor, Robin / Raaum, Odbjørn (1993): The Open Shop Union, Wages and Management Opposition, Oxford Economic Papers, 45, 589-604.

Neumann, George R. / Rissman, Ellen R. (1984): Where Have All the Union Members Gone?, Journal of Labor Economics, 2, 175-192.

Olson, Mancur (1965): The Logic of Collective Action, Cambridge, Mass.

Pencavel, John H. (1971): The Demand for Union Services: An Exercise, Industrial and Labor Relations Review, 24, 180-190.

Rij, Coen van / Daalder, Annelies (1997): The business cycle theory and individual unionization decisions: A comparison of macro- and micro influences on union membership, in: Sverke, Magnus (ed.), The Future of Trade Unionism, Aldershot, 235-248.

Riley, Nicola-Maria (1997): Determinants of Union Membership: A Review, Labour, 11, 265301.

Schelling, Thomas C. (1978): The Micromotives of Macrobehaviour, New York.

Schnabel, Claus (1989): Determinants of trade union growth and decline in the Federal Republic of Germany, European Sociological Review, 5, 133-146.

Schnabel, Claus (2003): Determinants of trade union membership, in: Addison, John T. I

Schnabel, Claus (eds.): International Handbook of Trade Unions, Cheltenham (forthcoming) 
Schnabel, Claus / Pege, Wolfgang (1992): Gewerkschaftsmitglieder: Zahlen, Strukturen, Perspektiven, Cologne.

Schnabel, Claus / Wagner, Joachim (2003): Trade Union Membership in Eastern and Western Germany: Convergence or Divergence?, Discussion Paper No. 18, Lehrstuhl für Arbeitsmarkt- und Regionalpolitik, Universität Erlangen-Nürnberg.

Schnell, Rainer / Kohler, Ulrich (1995): Empirische Untersuchung einer Individualisierungshypothese am Beispiel der Parteipräferenz von 1953-1992, Kölner Zeitschrift für Soziologie und Sozialpsychologie, 47, 634-657.

Streeck, Wolfgang (1981): Gewerkschaftliche Organisationsprobleme in der sozialstaatlichen Demokratie, Königstein, Ts.

Tajfel, Henri (ed.) (1982): Social Identity and Intergroup Relations, Cambridge: Cambridge University Press.

Terwey, Michael (2000): ALLBUS: A German General Social Survey, Schmollers Jahrbuch, $120,151-158$.

Visser, Jelle (2002): Why Fewer Workers Join Unions in Europe, British Journal of Industrial Relations, 40, 403-430.

Visser, Jelle (2003): Unions and Unionism around the World, in: Addison, John T. I Schnabel, Claus (eds.): International Handbook of Trade Unions, Cheltenham (forthcoming).

Waddington, Jeremy / Whitston, Colin (1997): Why Do People Join Unions in a Period of Membership Decline?, British Journal of Industrial Relations, 35, 515-546.

Wagner, Joachim (1991): Gewerkschaftsmitgliedschaft und Arbeitseinkommen in der Bundesrepublik Deutschland: Eine ökonometrische Analyse mit Individualdaten, Ifo-Studien, $37,109-140$.

Wallerstein, Michael (1989): Union Organization in Advanced Industrial Democracies, American Political Science Review, 83, 481-501.

Western, Bruce (1997): Between Class and Market - Postwar Unionization in the Capitalist Democracies, Princeton.

Wheeler, Hoyt N. / McClendon, John A. (1991): The Individual Decision to Unionize, in: Strauss, George / Gallagher, Daniel G. / Fiorito, Jack (eds.), The State of the Unions, Madison, WI, 47-83.

Windolf, Paul / Haas, Joachim (1989): Who joins the union? Determinants of trade union membership in West Germany 1976-1984, European Sociological Review, 5, 147-165. 
Table 1: Percentage of union members among West German employees, 1980-2000*

\begin{tabular}{|c|c|c|c|c|c|c|}
\hline & 1980 & 1984 & 1988 & 1992 & 1996 & 2000 \\
\hline All & $\begin{array}{c}32.7 \\
(30.0 / 35.5)\end{array}$ & $\begin{array}{c}31.6 \\
(28.9 / 34.5)\end{array}$ & $\begin{array}{c}29.4 \\
(26.7 / 32.2)\end{array}$ & $\begin{array}{c}28.7 \\
(25.8 / 31.7)\end{array}$ & $\begin{array}{c}26.6 \\
(23.9 / 29.5)\end{array}$ & $\begin{array}{c}25.4 \\
(22.4 / 28.6)\end{array}$ \\
\hline Male & $\begin{array}{c}39.6 \\
(36.1 / 43.2)\end{array}$ & $\begin{array}{c}38.7 \\
(35.1 / 42.4)\end{array}$ & $\begin{array}{c}37.5 \\
(33.8 / 41.3)\end{array}$ & $\begin{array}{c}36.0 \\
(32.0 / 40.2)\end{array}$ & $\begin{array}{c}33.8 \\
(29.9 / 37.8)\end{array}$ & $\begin{array}{c}31.0 \\
(26.8 / 35.5)\end{array}$ \\
\hline Female & $\begin{array}{c}20.3 \\
(16.6 / 24.5)\end{array}$ & $\begin{array}{c}19.0 \\
(15.3 / 23.3)\end{array}$ & $\begin{array}{c}16.9 \\
(13.5 / 20.8)\end{array}$ & $\begin{array}{c}18.5 \\
(14.8 / 22.7)\end{array}$ & $\begin{array}{c}16.3 \\
(12.8 / 20.2)\end{array}$ & $\begin{array}{c}17.7 \\
(13.8 / 22.3)\end{array}$ \\
\hline Blue collar & $\begin{array}{c}36.3 \\
(31.9 / 41.0)\end{array}$ & $\begin{array}{c}38.1 \\
(33.2 / 43.1)\end{array}$ & $\begin{array}{c}36.9 \\
(31.2 / 42.2)\end{array}$ & $\begin{array}{c}37.6 \\
(32.1 / 43.3)\end{array}$ & $\begin{array}{c}38.3 \\
(33.0 / 43.8)\end{array}$ & $\begin{array}{c}31.6 \\
(26.0 / 37.6)\end{array}$ \\
\hline White collar & $\begin{array}{c}26.3 \\
(22.6 / 30.1)\end{array}$ & $\begin{array}{c}20.1 \\
(16.8 / 23.8)\end{array}$ & $\begin{array}{c}22.1 \\
(18.3 / 25.6)\end{array}$ & $\begin{array}{c}20.2 \\
(16.8 / 23.9)\end{array}$ & $\begin{array}{c}16.2 \\
(13.3 / 19.6)\end{array}$ & $\begin{array}{c}18.5 \\
(14.9 / 22.6)\end{array}$ \\
\hline Civil servants & $\begin{array}{c}45.2 \\
(37.3 / 53.4)\end{array}$ & $\begin{array}{c}52.2 \\
(44.7 / 59.6)\end{array}$ & $\begin{array}{c}41.7 \\
(33.4 / 50.4)\end{array}$ & $\begin{array}{c}43.5 \\
(34.3 / 53.0)\end{array}$ & $\begin{array}{c}44.7 \\
(34.9 / 54.8)\end{array}$ & $\begin{array}{c}37.1 \\
(27.9 / 47.1)\end{array}$ \\
\hline
\end{tabular}

*Source: Own calculations based on the ALLBUS data for 1980-2000. Numbers in brackets are the lower/upper bounds of the binomial exact 95\% confidence interval 
Table 2: Results from estimations of union membership functions for West Germany Endogenous variable: Union member $(1=$ yes); Method: Probit

\begin{tabular}{|c|c|c|c|c|c|c|c|}
\hline Exogenous variable & 1980 & 1984 & 1988 & 1992 & 1996 & 2000 & Pooled data \\
\hline Age (years) & $\begin{array}{l}0.011^{* *} \\
(2.74)\end{array}$ & $\begin{array}{c}0.004 \\
(0.78)\end{array}$ & $\begin{array}{l}0.016^{* *} \\
(3.70)\end{array}$ & $\begin{array}{l}0.015^{* *} \\
(3.25)\end{array}$ & $\begin{array}{r}0.007 \\
(1.41)\end{array}$ & $\begin{array}{c}0.008 \\
(1.49)\end{array}$ & $\begin{array}{l}0.012^{* *} \\
(5.84)\end{array}$ \\
\hline Sex (dummy, $1=$ male) & $\begin{array}{l}0.270^{*} \\
(2.36)\end{array}$ & $\begin{array}{c}0.193 \\
(1.52)\end{array}$ & $\begin{array}{l}0.385^{* *} \\
(3.10)\end{array}$ & $\begin{array}{l}0.254^{*} \\
(1.98)\end{array}$ & $\begin{array}{l}0.350^{* *} \\
(2.67)\end{array}$ & $\begin{array}{c}0.208 \\
(1.46)\end{array}$ & $\begin{array}{l}0.310^{* *} \\
(5.55)\end{array}$ \\
\hline $\begin{array}{l}\text { Full time worker } \\
\text { (dummy, } 1=\text { yes) }\end{array}$ & $\begin{array}{l}0.429^{*} \\
(2.36) \\
\end{array}$ & $\begin{array}{r}0.313 \\
(1.61) \\
\end{array}$ & $\begin{array}{l}0.549^{* *} \\
(2.82) \\
\end{array}$ & $\begin{array}{l}0.668^{* *} \\
(3.45)\end{array}$ & $\begin{array}{l}0.471^{*} \\
(2.38) \\
\end{array}$ & $\begin{array}{l}0.547^{* *} \\
(2.59)\end{array}$ & $\begin{array}{l}0.524^{* *} \\
(6.11)\end{array}$ \\
\hline $\begin{array}{l}\text { Completed apprenticeship or } \\
\text { master craftsman (dummy, } 1=\text { yes) }\end{array}$ & $\begin{array}{l}0.379^{* *} \\
(2.62)\end{array}$ & $\begin{array}{c}0.202 \\
(1.26)\end{array}$ & $\begin{array}{c}0.248 \\
(1.68)\end{array}$ & $\begin{array}{r}0.064 \\
(0.46)\end{array}$ & $\begin{array}{l}-0.017 \\
(-0.12)\end{array}$ & $\begin{array}{l}-0.032 \\
(-0.17)\end{array}$ & $\begin{array}{r}0.120 \\
(1.86)\end{array}$ \\
\hline $\begin{array}{l}\text { Polytech or university } \\
\text { degree (dummy, } 1=\text { yes) }\end{array}$ & $\begin{array}{r}0.258 \\
(1.20)\end{array}$ & $\begin{array}{r}0.260 \\
(1.24) \\
\end{array}$ & $\begin{array}{l}-0.239 \\
(-1.17)\end{array}$ & $\begin{array}{l}-0.171 \\
(-0.97)\end{array}$ & $\begin{array}{l}-0.362^{*} \\
(-1.97)\end{array}$ & $\begin{array}{l}-0.443 \\
(-1.91) \\
\end{array}$ & $\begin{array}{l}-0.220^{*} \\
(-2.52)\end{array}$ \\
\hline $\begin{array}{l}\text { Blue collar worker } \\
\text { (dummy, } 1=\text { yes) }\end{array}$ & $\begin{array}{r}0.129 \\
(1.19)\end{array}$ & $\begin{array}{l}0.404^{* *} \\
(3.28)\end{array}$ & $\begin{array}{l}0.334^{* *} \\
(2.70)\end{array}$ & $\begin{array}{l}0.443^{* *} \\
(3.60)\end{array}$ & $\begin{array}{l}0.617^{* *} \\
(4.77)\end{array}$ & $\begin{array}{l}0.366^{* *} \\
(2.59)\end{array}$ & $\begin{array}{l}0.350^{* *} \\
(6.47)\end{array}$ \\
\hline $\begin{array}{l}\text { Civil servant } \\
\text { (dummy, } 1=\text { yes) }\end{array}$ & $\begin{array}{l}0.453^{*} \\
(2.55)\end{array}$ & $\begin{array}{l}0.595^{* *} \\
(3.56)\end{array}$ & $\begin{array}{r}0.325 \\
(1.66)\end{array}$ & $\begin{array}{l}0.458^{*} \\
(2.51)\end{array}$ & $\begin{array}{l}0.615^{* *} \\
(3.10)\end{array}$ & $\begin{array}{l}0.664^{* *} \\
(3.15)\end{array}$ & $\begin{array}{l}0.501^{* *} \\
(5.97)\end{array}$ \\
\hline $\begin{array}{l}\text { Public sector employee } \\
\text { (dummy, } 1 \text { = yes) }\end{array}$ & $\begin{array}{r}0.162 \\
(1.20)\end{array}$ & $\begin{array}{l}0.480^{* *} \\
(3.37)\end{array}$ & $\begin{array}{l}0.341^{*} \\
(2.36)\end{array}$ & $\begin{array}{l}0.356^{* *} \\
(2.58)\end{array}$ & $\begin{array}{l}0.373^{* *} \\
(2.73)\end{array}$ & $\begin{array}{r}0.025 \\
(0.16)\end{array}$ & $\begin{array}{l}0.214^{* *} \\
(3.90)\end{array}$ \\
\hline $\begin{array}{l}\text { Size of village/city (index from } 1= \\
\text { small to } 7=\text { large) }\end{array}$ & $\begin{array}{r}0.026 \\
(1.08) \\
\end{array}$ & $\begin{array}{r}0.008 \\
(0.30) \\
\end{array}$ & $\begin{array}{l}0.058^{*} \\
(2.14)\end{array}$ & $\begin{array}{r}0.043 \\
(1.50)\end{array}$ & $\begin{array}{r}0.049 \\
(1.61) \\
\end{array}$ & $\begin{array}{l}0.109^{* *} \\
(3.23)\end{array}$ & $\begin{array}{l}0.053^{* *} \\
(4.23)\end{array}$ \\
\hline $\begin{array}{l}\text { Political orientation (index from } 1= \\
\text { extreme left to } 10=\text { extreme right) }\end{array}$ & $\begin{array}{l}-0.083^{* *} \\
(-3.30)\end{array}$ & $-1)$ & $\begin{array}{l}-0.162^{* *} \\
(-5.60)\end{array}$ & $\begin{array}{l}-0.069^{*} \\
(-2.46)\end{array}$ & $\begin{array}{l}-0.121^{* *} \\
(-4.10)\end{array}$ & $\begin{array}{l}-0.112^{* *} \\
(-3.09)\end{array}$ & $\begin{array}{l}-0.105^{* *} \\
(-8.26)\end{array}$ \\
\hline $\begin{array}{l}\text { Father: blue collar worker } \\
\text { (dummy, } 1=\text { yes) }\end{array}$ & $\begin{array}{l}0.243^{*} \\
(2.52)\end{array}$ & $\begin{array}{r}0.202 \\
(1.92) \\
\end{array}$ & $\begin{array}{l}-0.093 \\
(-0.90) \\
\end{array}$ & $\begin{array}{l}0.325^{* *} \\
(3.01)\end{array}$ & $\begin{array}{r}0.114 \\
(1.04) \\
\end{array}$ & $\begin{array}{r}0.101 \\
(0.80) \\
\end{array}$ & $\begin{array}{l}0.131^{* *} \\
(2.76)\end{array}$ \\
\hline $\begin{array}{l}\text { Firm size } \\
\text { (number of employees) }\end{array}$ & $\begin{array}{l}7.11 \mathrm{e}-5^{* *} \\
(2.76)\end{array}$ & $\begin{array}{l}5.97 \text { e-5** } \\
(3.18)\end{array}$ & $(1)$ & $-1)$ & $-1)$ & $-1)$ & \\
\hline Firm size squared & $\begin{array}{l}-1.20 \mathrm{e}-9^{*} \\
(-2.20)\end{array}$ & $\begin{array}{l}-5.90 \text { e-10* } \\
(-2.31)\end{array}$ & $-1)$ & $-1)$ & $-1)$ & $-1)$ & \\
\hline Time dummies & & & & & & & yes $^{* *}$ \\
\hline Constant & $\begin{array}{l}-1.730^{* *} \\
(-5.33)\end{array}$ & $\begin{array}{l}-1.770^{* *} \\
(-5.70)\end{array}$ & $\begin{array}{l}-1.714^{* *} \\
(-5.07)\end{array}$ & $\begin{array}{l}-2.223^{* *} \\
(-6.24)\end{array}$ & $\begin{array}{l}-1.552^{* *} \\
(-4.24)\end{array}$ & $\begin{array}{l}-1.695^{* *} \\
(-4.19)\end{array}$ & $\begin{array}{l}-1.625^{* *} \\
(-9.98)\end{array}$ \\
\hline Number of observations & 916 & 812 & 847 & 746 & 788 & 632 & 3952 \\
\hline
\end{tabular}

Notes: z-values in brackets; $\left.{ }^{*}{ }^{* *}\right)$ denote statistical significance at the $5(1)$ percent level; ${ }^{1}$ information not available from the survey 


\section{IZA Discussion Papers}

\begin{tabular}{|c|c|c|c|c|}
\hline No. & Author(s) & Title & Area & Date \\
\hline 693 & $\begin{array}{l}\text { L. Gobillon } \\
\text { H. Selod } \\
\text { Y. Zenou }\end{array}$ & $\begin{array}{l}\text { Spatial Mismatch: From the Hypothesis to the } \\
\text { Theories }\end{array}$ & 3 & $01 / 03$ \\
\hline 694 & E. S. Prasad & $\begin{array}{l}\text { What Determines the Reservation Wages of } \\
\text { Unemployed Workers? New Evidence from } \\
\text { German Micro Data }\end{array}$ & 3 & $01 / 03$ \\
\hline 695 & $\begin{array}{l}\text { S. Alan } \\
\text { T. F. Crossley } \\
\text { P. Grootendorst } \\
\text { M. R. Veall }\end{array}$ & $\begin{array}{l}\text { Out-of-Pocket Prescription Drug Expenditures } \\
\text { and Public Prescription Drug Programs }\end{array}$ & 3 & $01 / 03$ \\
\hline 696 & R. Schettkat & $\begin{array}{l}\text { Institutions in the Economic Fitness Landscape: } \\
\text { What Impact Do Welfare State Institutions Have } \\
\text { on Economic Performance? }\end{array}$ & 3 & $01 / 03$ \\
\hline 697 & R. Schettkat & $\begin{array}{l}\text { Differences in US-German Time-Allocation: } \\
\text { Why Do Americans Work Longer Hours than } \\
\text { Germans? }\end{array}$ & 5 & $01 / 03$ \\
\hline 698 & $\begin{array}{l}\text { T. M. Andersen } \\
\text { J. R. Skaksen }\end{array}$ & $\begin{array}{l}\text { Product Market Integration, Comparative } \\
\text { Advantages and Labour Market Performance }\end{array}$ & 2 & $01 / 03$ \\
\hline 699 & $\begin{array}{l}\text { D. Margolis } \\
\text { V. Simonnet }\end{array}$ & $\begin{array}{l}\text { Educational Track, Networks and Labor Market } \\
\text { Outcomes }\end{array}$ & 2 & $01 / 03$ \\
\hline 700 & T. K. Bauer & $\begin{array}{l}\text { Flexible Workplace Practices and Labor } \\
\text { Productivity }\end{array}$ & 1 & $01 / 03$ \\
\hline 701 & $\begin{array}{l}\text { L. Goerke } \\
\text { J. B. Madsen }\end{array}$ & $\begin{array}{l}\text { Earnings-Related Unemployment Benefits in a } \\
\text { Unionised Economy }\end{array}$ & 3 & $01 / 03$ \\
\hline 702 & $\begin{array}{l}\text { M. Ayhan Kose } \\
\text { E. S. Prasad } \\
\text { M. E. Terrones }\end{array}$ & $\begin{array}{l}\text { How Does Globalization Affect the } \\
\text { Synchronization of Business Cycles? }\end{array}$ & 2 & $01 / 03$ \\
\hline 703 & $\begin{array}{l}\text { W. C. Horrace } \\
\text { R. L. Oaxaca }\end{array}$ & $\begin{array}{l}\text { New Wine in Old Bottles: A Sequential } \\
\text { Estimation Technique for the LPM }\end{array}$ & 6 & $01 / 03$ \\
\hline 704 & $\begin{array}{l}\text { M. Ransom } \\
\text { R. L. Oaxaca }\end{array}$ & Intrafirm Mobility and Sex Differences in Pay & 1 & $01 / 03$ \\
\hline 705 & $\begin{array}{l}\text { G. Brunello } \\
\text { D. Checchi }\end{array}$ & School Quality and Family Background in Italy & 2 & $01 / 03$ \\
\hline 706 & $\begin{array}{l}\text { S. Girma } \\
\text { H. Görg }\end{array}$ & $\begin{array}{l}\text { Blessing or Curse? Domestic Plants' Survival } \\
\text { and Employment Prospects after Foreign } \\
\text { Acquisitions }\end{array}$ & 1 & $01 / 03$ \\
\hline 707 & $\begin{array}{l}\text { C. Schnabel } \\
\text { J. Wagner }\end{array}$ & $\begin{array}{l}\text { Trade Union Membership in Eastern and } \\
\text { Western Germany: Convergence or } \\
\text { Divergence? }\end{array}$ & 3 & $01 / 03$ \\
\hline 708 & $\begin{array}{l}\text { C. Schnabel } \\
\text { J. Wagner }\end{array}$ & $\begin{array}{l}\text { Determinants of Trade Union Membership in } \\
\text { Western Germany: Evidence from Micro Data, } \\
\text { 1980-2000 }\end{array}$ & 3 & $01 / 03$ \\
\hline
\end{tabular}

An updated list of IZA Discussion Papers is available on the center's homepage www.iza.org. 